\title{
The "Native Experiment": the formation of the Bantu Presbyterian Church and the defects of faith transplanted on African soil
}

\section{Vuyani S. Vellem ${ }^{1}$}

\section{Abstract}

The missionary institutionalization of the Church of Christ, ipso facto, the formation of the Bantu Presbyterian Church in South Africa (BPC), is a tale of ambivalence and 'original' defects of faith in a visible form of a Church. A product of the Scottish missionary enterprise in South Africa, the BPC is a tale of unequal racist relations between white and black - a tale of 'naming' and 'practical considerations' at the whims and desires of those who transplanted the gospel in this land. While this paper presents the history of the BPC's formation, its purpose is illustrative. By the time of its formation in 1923, two distinct approaches to the gospel were already in existence: a white, anaemic interpretation of the gospel and a black critical and refusing one. The paper therefore argues that 'blackness' is not to be found in colonizing and coercing missionary institutions such as in the formation of the BPC, but in the irruption of a faith that refused patronage, rejected racial inequality and signification by others.

Keywords: Black faith, defects, 'native experiment,' subtle, signification

\section{Introduction}

It is hard to contemplate the future of the church in South Africa, and probably of the entire globe without confronting the deficient structures and forms of faith that were transplanted by the missionaries in Africa and South Africa in particular. Indeed the refusal of black Christians to accept "an anaemic gospel of subservience and dejection-both in the blatant forms of a hundred years ago and the subtler forms of the present” (Boesak 2009:49) is the motivation for this essay to go back into the formation of what was then dubbed the "Native Experiment."

The struggle for an authentic black church in South Africa requires our reflection as black scholars on the white control of the church, the polities that were transplanted by the missionaries and the preponderance of alien forms of theology and thus faith, particularly their subtler forms post 1994 as Boesak has rightly asserted above.

The debate for the formation of the Bantu Presbyterian Church in Southern Africa (BPCSA), henceforth BPC, took place in an ambivalent context. This ambivalence stemmed, inter alia, out of the racial conflict that affected all mission work in South Africa and the Scottish missionary enterprise alike. One example that signifies the roughness of the conflict

1 Vuyani Vellem is senior lecturer in Dogmatics and Christian Ethics at the University of Pretoria. He can be contacted at vuyani.vellem@up.ac.za 
blacks had with the missionary enterprise is the Ethiopian Movement which captured the spirit of black ministers in response to the racial bigotry of the 19th century missionary enterprise and its defective teachings which are still with us even to this day. By the time the BPC was formed in 1923, whites with their Christian teachings had attained total exclusion and oppression of black people in public life. The bloody dispossession in protracted wars designated by some as "Frontier Wars" in the Eastern Cape and the laws that totalized the exclusion and oppression of blacks by the time of the formation of the South African Union in 1910 and after, define the space within which Christendom flourished in South Africa.

For example, the BPC came into existence after the Anglo-Boer War; World War I; the discovery of diamonds and gold; the Union of South Africa and the passing of laws such as the Land Act of 1913 to mention but a few. This paper therefore, seeks to offer a reflection from a black perspective on this historical text of the formation of the BPC. In essence, it is not so much of the history of the BPC that is offered here, albeit important given the fact that there is virtually nothing published on this history, but the paradigmatic text it offers as one of the fewest institutions ${ }^{2}$ led by blacks before 1994 in South Africa.

The BPC was renamed the Reformed Presbyterian Church in Southern Africa (RPC) in 1982 within the epoch of the Soweto uprisings and got into union with the Presbyterian Church of South Africa (PCSA) in September 1999 in Port Elizabeth to form the current Uniting Presbyterian Church in Southern Africa (UPCSA). In offering a reflection on the history of the formation of the BPC, in itself a microcosm of the macrocosm of the South African challenges post 1994, my subliminal text is to demonstrate that questions that might subtly bedevil our current context in the church and public life are century long defects we can evade only at our peril for the future of the church and public life. My focus then is to assess the reasons behind the formation of the BPC. My assessment of the reasons that were propounded to form the BPC brings to light the defects of faith that were inseminated by the missionary enterprise in South Africa, let alone in the precarious context that arose as many blacks, including the very first elite

2 One institution that comes to mind is the Federal Theological Seminary in Southern Africa, Fedsem which closed down in 1992. Cf. Phillipe, D. \& Duncan, G. 2011.The Native School that caused all the Trouble: The History of the Federal Theological Seminary. Pietermaritzburg: Cluster Theological Publications. My reading of this work leaves me with one question in mind. Was the response to the brutality of the state, acknowledged throughout the book, which Fedsem so quintessentially epitomized not a matter of faith? I dare say the South African Council of Churches which is currently under sever strains since the leadership of Archbishop Desmond Tutu was a black led institution whose history might equally help us reflect on the meaning of what black faith is in contrast to the alienating forms of faith transplanted by the missionary enterprise in South Africa. 
products of the Scottish missions, later rejected the missionary paradigm and the dominance of whites in the church and in South Africa in general. Indeed, if Black Theology of liberation is understood as a response to modernity too, Bosch's assessment of "mission in the wake of the Enlightenment" (1991:262-345) clarifies the motif of reason and thus the dichotomies and dualist worldview of faith within which the encounter between Western Christianity and Africa took place. I am led to conclude that this historical text of the formation of the BPC, a "Native Experiment," offers one of the earliest examples of ambivalence in black faith, ipso facto, a faith distinguished by blacks in their struggle against the ubiquitous defects of white faith and dominance right through into the post 1994 South Africa.

\section{Presbyterian Traditions in South Africa}

The word "tradition" is used in this particular instance to designate various streams of the origins of Presbyterianism in South Africa. In this sense, there were different Presbyterian traditions in South Africa, yet at the same time the word could also designate variants in Presbyterianism strands, such as the Indian which is more episcopal in polity. Indeed, with a number of unifications that saw the light in the 20th century, bringing Methodists, Congregationalists and Presbyterians together to form united churches, no further elucidation of the use of the term 'tradition' is necessary. If one were to consider even the union between the former Reformed Presbyterian Church in Southern Africa and the Presbyterian Church in Southern Africa in 1999, then my use of the term "tradition" would be crystal clear.

The former RPCSA was a product of the missions, while the former PCSA was a product of the Settler tradition in South Africa. It is therefore important to understand the use of this term as from the very beginning. I discount any view that seeks to suggest one form of Presbyterianism even in the context of its historical development in South Africa as historically incorrect, but also ideological. Such a view would suggest that an African tradition of Presbyterianism is not feasible a development except on the basis of being a carbon copy of the European forms of Presbyterianism. The histories of the Evangelical Presbyterian Church in South Africa (EPCSA), the Bantu Presbyterian Church in Southern Africa (BPC), the Presbyterian Church of South Africa (PCSA), the Uniting Presbyterian Church in Southern Africa (UPCSA), are ramifications of various traditions of Presbyterianism in South Africa. Prior to the formation of the BPC, there were four traditions of Presbyterianism already in existence on our shores, namely, the Free Church, the United Presbyterian, the Swiss Mission and the Settler ${ }^{3}$ Presbyterian traditions.

3 The term 'settler' might be interpreted as loaded or even disparaging in the 'new' South Africa, but I intend to denote a tradition of Presbyterianism that began among the British and Scottish settlers related to the fashionable phrase '1820 Settlers' in South African 
It is the Free Church of Scotland that formed this 'Native' Church, the BPC, out of its missionary work in South Africa.

\section{Talks for the Formation of the BPC}

From as early as 1892 to 1897 , there were talks among all the Presbyterian traditions to establish one Presbyterian Church in South Africa. In this period alone, these traditions met on six different occasions to discuss proposals for union and to draw up a common basis of union which could be acceptable to all of them. To spearhead these union negotiations, a body called the Federal Council (FC) had been established which later constituted itself as the First General Assembly of the Presbyterian Church of South Africa (PCSA) on the 17th day of September 1897. Van der Spuy portrays the picture of the formation of the PCSA in this manner:

The historic 6th Federal Council met on the evening of the 17th September,1897, and was later to constitute itself as the first General Assembly of the Presbyterian Church of South Africa (1971:32).

Most of the Presbyteries that comprised the newly formed Church, i.e. the PCSA, were made up of settlers from Britain most of whom arrived in South Africa in 1820.

The new Church was not a product of the missionary work in South Africa, but one of a gathering of professed Presbyterians and associates who intended to form their own independent Church. The proposed union of all the Presbyterian traditions that led to the formation of the FC clearly did not materialize as envisaged. The FC declared itself as the PCSA. It seems the pursuit of this union, intended for the various Presbyterian traditions posed problems as solutions and models of this union were sought between a divided, federally cooperating, or multi-racial church after the FC declared itself the PCSA. The Free Church Synod of Kaffraria, which was preponderantly black in membership declined to enter into union and the following is an elaborate minute in this regard:

While the Synod recognized the desirability of union among various branches of the Presbyterian Church in South Africa, and hopes that existing obstacles may be removed in course of time, they are unable to enter in the proposed union at present in consequence of the want of acquiescence on the part of several of the native congregations in two Presbyteries, and in view of discussions which have arisen among Europeans on the subject of the Native vote in Church courts. The Synod agree to indicate two different directions in which some modification of the arrangements contemplated in the united Church is necessary in order to remove these obstacles. First, that some method be devised of adjusting the balance between Colonial and

history. Naming is still a problem in South African ecclesiastical history as terms such as 'main-line churches,' 'African Initiated Churches' cannot go without any note of explanation. 
Mission Churches, which shall be satisfactory to both races; e.g., that a majority of white and a majority of black, separately and conjointly, necessary to pass the proposed measure into law, the proportion of both races in the General Assembly be strictly defined and preserved. Second, that there be a final Court of Appeal in certain questions be carefully defined, say, to a Board at Home representative of the British Isles, or even of wider range, such as the Pan-Presbyterian Council could easily furnish (Proceedings of the General Assembly of the PCSA 1897: 6-7).

What is ultimately clear in the minute above is that the crux of the matter was the rejection of the terms of union by blacks "in several of the congregations in two Presbyteries" that were part of the Synod of Kaffraria. The issue of the vote in the Church courts of the proposed new Church implies the inequality of power sharing in the proposed new Church. That such inequality was already prevalent outside the structure of the Church in general in South Africa suggests only one reason for such a proposed dissonant model of union: racism.

The extent of racial conflict and tension meant that there was no trust between blacks and whites with an appeal for a wide representation such as the Pan African Council as a resort, at least from the black perspective. For this reason the Free Church and United Presbyteries chose to stay out of the newly formed Church, the PCSA. Both these presbyteries had a large number of black congregations. The PCSA thus became a preponderantly white Settler Church.

\section{Reasons leading to the Formation of a 'Native Church'}

There were two opposing views for the establishment of a black Church. On the one hand there were those who held that one multiracial church would be better than a church established on racial lines. On the other hand there were those who favoured the notion of establishing "a Native Experiment" - a self-supporting, self-sufficient propagating Native Church. The United Free Church of Scotland's General Assembly favoured the option of one Presbyterian Church in South Africa. The reason that made the United Free Church of Scotland to entertain this view was that the two "parent" Churches in Scotland from which the South African Presbyterian traditions of the Free Church and the United Presbyterian respectively originated, united in 1900 after a half-of-a-century split in what was called the "Great Disruption." There was a wish in Scotland that their unity could influence their own two sections of mission in South Africa, one which was an integral part of the PCSA and the other distinct with a large measure of local self-government.

4 The Great Disruption was a major event in the religious history of Scotland. In 1834 the Church of Scotland was rent apart leading to the formation of the Free Church of Scotland. Cf. Kenneth Latourette, pp.1192-1196 and (Denise Van der Spuy 1971: 6-8). 
While the wish in principle sounded noble, it did have its own problems when there were attempts to concretize it. After the formation of the PCSA in 1897, and the period ensuing up to 1920, the discussion of union shifted and was centred on Presbyterian missions, which were largely black, uniting to form one Church. In other words the collapse of the envisaged union of all Presbyterian traditions as a result of the formation of the PCSA in 1897 became a catalyst for union talks among the missionary initiated black congregations. For some strange reasons, the PCSA also got involved and in the 1920 General Assembly of the PCSA, through the report of "the Conference of the Union of Presbyterian Missions" advocated for a Native Church in Federal relationship with the PCSA. The report of "the Conference of the Union of Presbyterian Missions" in the records of the PCSA portrays this matter in the following manner:

It will be seen that the vital issue is concerned with the relationship of the proposed Native Church to the Presbyterian Church of South Africa. Is it to be organic or subordinate relationship? Having regard to the weight of evidence, the Conference decided in favour of the latter. It was however felt and strongly urged that compatible with this condition of independence, the relationship between the European and the Native Churches should be as close and as vital as possible. The two races need each other. Their future in Church and State are inextricably bound together. The problem of uniting fragments of our missions has long been before the Church. Reckless haste must be avoided. But we dare not remain inactive. We may miss the tide (Proceedings of the 21st General Assembly of the PCSA 1920: 121-122).

What this means is that the PCSA at the General Assembly in 1920 accepted a relationship that was not organic but unequal, a "subordinate relationship". That the "weight of evidence" was in favour of a subordinate relationship could only make sense if we return to the reasons that made the very first round of union negotiations to fail, namely, racial inequality. In this same year of the report of the "Conference of the Union of Presbyterian Missions", the Deputies of the Foreign Mission, the Rev Frank Aschroft and Mr Andrew Houston ${ }^{5}$, were present at the Assembly of the PCSA. They were given the opportunity to address the PCSA Assembly and apparently they had come to investigate the desirability of union of Presbyterians in South Africa. To the report of the "Conference of the Union of Presbyterian Missions" cited above, the PCSA's response was that the Presbyteries of Kaffraria, Mankazana and the Synod of Kaffraria be given full power to decide on the question of union, according to Van der Spuy (1971:39). However, the question of the union, or the relationship between the PCSA and the impending union of the Missions had to be "left for future consideration."

The PCSA Assembly further appointed a committee to attend the conference that Aschroft and Houston were scheduled to have with the

5 About the visit of these Deputies see also Oosthuizen (1970: 101) 
Synod of Kaffraria, the Presbyteries of Kaffraria and Mankanza at Blythswood on the 20th October 1920.

In a nut-shell, the Deputies, Aschroft and Houston, in their report back home in Scotland gave reasons for the decision to form the Bantu Presbyterian Church. They felt that the period of missionary expansion was over. The Mission Council in South Africa was also failing to play a unifying role. There were objections of course against the formation of the BPC. Some felt that the formation of the BPC was based on anti white bias in some of the native congregations and therefore the danger that the BPC might be captured by a political party that is hostile to the British government was troubling their minds. The Deputies felt that the repression of the 'natives' could not be the best solution and that they should rather be allowed a greater voice in their own affairs. The Synod of Kaffraria, stood for an independent 'native' Church, free of white control. The Presbytery of Kaffraria clamoured for a South African Presbyterian Church in which black and white congregations had their place under the same General Assembly (Van der Spuy 1971:39). Well, in the context of these contending views the Deputies were in favour of the establishment of a 'native' church because:

During their visit to the General Assembly they became convinced that it was not a suitable court for native matters. The difference of language and social condition are too considerable, and they sympathised with the irritation of the native ministers in being there at the consideration of business wholly connected with the colonial church (Van der Spuy: 39-40).

Another factor we cannot overlook is the role that James Stewart prominently played in the union talks. He is an architect of what later became Apartheid education for blacks in South Africa ${ }^{6}$. According to Van der Spuy, Stewart held this position:

He pled for a fully organized native church in federal relations with the church at home. In addition to financial reasons, he urged that the proposed union would be harmful to mission interests; that the members of the Colonial Church as a whole were unwilling to receive the Native congregations on equal terms; that the native section of the Church, being the larger would submerge the European Section; that the Europeans would not consent to be ruled by a native majority; and that this proposed union would hinder union with the DRC (Van der Spuy: 34-35).

James Stewart pondered a "native church in federal relations" with his Church at home as he disagreed with the same Church at home which envisaged a union of all Presbyterians under a single jurisdiction. Van der Spuy (1971:35) argues that James Stewart's position was motivated by "political and practical considerations." To this notion we shall return. One

6 See Simon Gqubule (1977), De Kock (1992), Duncan (2003) 
of the episodes in South African Church history at this time was that of the Ethiopian Movement. This was an irruption by the black ministers in a number of missions across the denominational spectrum who decided to leave most of the churches that were formed by the missionaries to form black churches. The formation of the Presbyterian Church of Africa (PCA), led by the Rev Mpambani Mzimba, himself a product of the Scottish Missions, was part of this movement. For some reason this influenced James Stewart to argue against the formation of the BPC in addition to what I have cited above. About this Van der Spuy says, "One cannot help but wonder how great an influence the Mzimba secession was in his conclusions" (1971: 35). Graham Duncan's view is also illuminating even though its focus is on Lovedale:

Lovedale's leaders seemed to have been oblivious to external influences and issues which had been fermenting for some time. Dr Stewart could speak with conviction of 'the recent unaccountable movement know (sic) as the Ethiopian Church began, which has affected every mission in South Africa. Its aim seems to be a kind of ecclesiastical Home Rule, and it has done nothing but mischief... (2003:214).

That the Ethiopian Movement was a factor that prompted different responses by the missionaries is supported also by what Chris Nissen says about two options available for them:

The one was that they wanted to allow a Native church to develop on its own under the direction of the European missionaries until such time that the Native church is mature enough to be wholly on its own. Whether they were genuine about it is not clear. The second, yet not so explicit is the fact that Mzimba's Church still drew from the Free Church of Scotland mission stations a considerable part of his membership. The Ethiopian Movement's presence and Mzimba's example were strongly felt amidst the "native" Christians. (Nissen 1989:n.p.)

The implication of the sentiments above is that the Ethiopian Movement became a factor in the formation of the BPC and the missionaries had to either allow the existence of a black church under their patronage, or feared a walk out of black Christians who were captured by the spirit of the moment, the Ethiopian Movement. James Stewart is among those who feared and got disappointed by the emergence of the Ethiopian Movement. It is also important to clarify that naming the Ethiopian Movement a secessionist phenomenon is not just a misunderstanding of this black response, but an affront to it. Allan Boesak designates the Ethiopian Movement an expression of a "theology of refusal":

This theology of refusal has been the theology of the great black leaders; to name but a few: Denmark Vessey, Frederick Douglass, W.E.B. Dubois, Martin Luther King Jr., Nehemiah Tile, Mangana Mokone and Albert 
Luthuli... This is the theology the black church must make its own if it is to survive, if it is to become truly 'church' (2009:55-56).

What this means therefore is that the Ethiopian Movement was not a secessionist movement, but a refusing movement that rejected and hated racial bigotry for the love of the gospel.

The motivation to form a "native church" for fear of the exodus of black people not into Mziba's PCA per se, but the movement committed and inspired by a theology of refusal must have been indeed, consciously or unconsciously, a refusal for the existence of an authentic black church with a unique faith. As I have already indicated earlier, the Deputies from Scotland also thought that the PCSA was not a suitable Supreme Court for black interests. They supported the formation of an African Church in which African ministers and elders would have "a real voice." Subsequent to the Conference that sat at Blythswood, a commission was instituted with the view to uniting different sections of the United Free Church of Scotland for the purpose of forming an African Church. The Commission which came into existence at the insistence of the Deputies from Scotland had a series of meetings at Lovedale. According to D. V. Sikhutshwa (1946: 7), the missions that agreed to unite were:

The Synod of Kaffraria, the Presbytery of Kaffraria; the Presbytery of Mankazana; the Mission Council of Natal. The Presbyterian Church of South Africa readily agreed to set free the Presbytery of Mankazana and Kaffraria by furnishing with disjunction certificates all who asked for them, to enter Union.

Sikhutshwa provides an elaborate account of the stages and the crucial matters that the Commission dealt with up to the consummation of the union on the bodies that came to form the BPC. On the 4th of July 1923, the Commission met at Lovedale. In the evening, on the 11 July 1923, the Bantu Presbyterian Church of South Africa was constituted. The Rev William Stewart was elected the first Moderator of its General Assembly. This event was widely accorded publicity, the media reporting about the formation of a black church. Spiwo Xapile records that the formation of the BPC was given wide coverage in Imvo Zabantsundu. He goes on to say that the BPC "became the most notable experiment in South African Missionary enterprise," (1992:12). It was indicated that the name "Bantu" was not meant to imply any racial exclusion more than it explained the nature of its membership.

Van der Spuy also says "At the time, granting full autonomy to a Native Church was something completely new in South African society. The new experiment would be anxiously watched as an indicator for the future" (1971:41). The title of this article takes its cue from this background. Whose experiment was the formation of the BPC? The signification "experiment" 
is too loaded! But what also Van der Spuy says is instructive to capture the white spirit in this regard:

The future possibilities were wide open for the new Church, yet it was placed in a paradoxical position for while it claimed universality and colour-blindness, its very name, composition and future relationships proclaimed something different. The attempt to carry out the broad Christian and Biblical commission as in Matt. 28:19, as well as maintain its social standpoints in the South African context was bound to create a crisis of faith, even if not fully realized (1971:45).

How ironic indeed! Think about the formation of the PCSA earlier in 1897 which excluded blacks. Furthermore the name, the composition, the Commission and the social context were all the designs of the missionaries, yet there was fear as the sentiments above indicate, of the creation of a "crisis of faith." Yes indeed, a crisis of faith, as we elaborate more on the reasons propounded to form this "Experiment”, had been created.

\section{Engaging the Reasons Propounded for the Formation of a "Native" Church}

The reasons that were given to form this Church require serious engagement. From a black perspective, it is necessary to debunk these reasons in order to establish if the motivation to form the BPC was genuine and resonant with what Black Theology of liberation understands as a black church in general.

\section{The relationship between the PCSA and the BPC}

The fact that the Settler Community declared itself into a Church which even received recognition by the Church of Scotland cannot be overlooked. The PCSA was largely a congregation of Settlers who were in South Africa for political reasons. They were here to consolidate the power of the British Empire. Most European missionaries argued for the establishment of multi racial churches which would otherwise not be helpful to deal with the foreignness of Christianity on African soil. The model the PCSA sought to espouse is intriguing. First, the PCSA developed its own "native mission." This is the same PCSA which found it difficult or almost impossible to unite with preponderantly black missions to form one church. This question was to arise later in the 1950s when the PCSA and the BPC engaged once again in union talks. The PCSA at first was only prepared to negotiate union with the PBC through its African Missions Committee:

7 It is now common knowledge that African bodies were dishonoured in scientific experiments in colonial times. The African body was not only disfigured and dismembered throughout the centuries of black oppression, but it was also despised and dehumanised. 
The African Missions Committee of the Presbyterian Church of South Africa proposed a union of the two churches on the basis of the Book of Order of the Presbyterian Church of South Africa and particularly its chapter on Missions (Xapile 1992: 22).

A suitable body for the union of the two was according to the PCSA a department, or unit that dealt with the PCSA's missions. The BPC was thus not a credible Church made up of equal human beings in ecclesiastical matters as viewed by the PCSA. The unsavoury relations between the BPC and PCSA could be discerned from a very long history of union talks before the formation of the BPC and after its formation in 1923 and through the 1950s up to $1971 .^{8}$

For this reason, even though it is ultimately not possible to argue that there was only one wrong side in this history, my point, confined to the evidence of inequalities of race in the very earliest if not the origins of these talks, suggests that the PCSA and BPC were never equal.

\section{The Name}

That the name "Bantu" reflected no racial undertones but rather explained the preponderance of membership is not satisfactory. Initially, the Commission that was instituted to facilitated union talks of the Native Missions proposed the name "United Presbyterian Church." It was at the influence of the Presbyterian Church of South Africa that the name was changed to "Bantu." About this Van der Spuy says:

...the Assembly agreed to the Federal relationship, but objected strongly to the name of the proposed new body and sent a communication to the Commission. It pointed out that the Assembly agreed to facilitate a Native Church in federal relation with the P.C.S.A. and that the name of the proposed new body failed to make this clear and further would lead to confusion in the public mind. The intension was that this new church was for the Native peoples and the Assembly requested that the name be altered (1971:42).

This submission by the General Assembly of the PCSA resulted in the alteration of the name. The name "Bantu" was thus a name by whites. Their interest was to have a federal relationship with 'natives.' A federal relationship was in actual fact "separate development," a pillar of the heresy of Apartheid later in the history of South Africa. In this name, black are defined by whiteness. Charles Long's theory of signification is appropriate at this juncture:

8 Spiwo Xapile in his doctoral thesis discusses the history of the union of the two Churches from 1923 to 1971 . He divides this history into two sections or chapters to be precise: "Talks about a possibility for unity 1923-1959" and “ Serious unity talks begin (1959-1971).” 
By signification I am pointing to one of the ways in which names are given to realties and peoples during this period of conquest; this naming is at the same time an objectification through categories and concepts of those realities which appear as novel and "other" to the cultures of conquest (1986:4).

No one in post 1994 South Africa who is familiar with the struggle of liberation will fail to remember how naming was central to the objectification of black by "novel and 'other'” categories of whiteness to use the mildest terms above. In this name, this Church was being signified!

\section{Practical Considerations}

The phrase "practical considerations" cited by Van der Spuy to explain Stewart's position in favour of a separate native Church sounds the same as the explanation given to explain the 1857 synodical concession that whites be allowed to worship separately ten gevolge van de zwakheid van somigen - 'due to the weakness of some'. Willem Saayman ${ }^{9}$ also argues that the separate missions in the DRC were granted purely on pragmatic grounds. It is said that this concession was granted in order not to hinder the progress of the kingdom of God among the heathens. Saayman however agrees that this pragmatic concession did lead to the founding of the racially separated missions in the DRC (1983:136).

He understands this pragmatic concession on the basis of conflict between black and white in the Cape Colony, explicable in the Frontier Wars that stood as a testimony of bloodshed in the colonists' endeavours to expand their borders in South Africa. The arrival of Settlers contributed to a situation where a "transplanted older European church came into existence right in its own mission field," Saayman (1983:136) contends. As a result of the socio-political situation and practical considerations, racial cooperation was abandoned in favour of racially separated churches. This is reminiscent of the argument advanced by Van der Spuy. He acknowledges that the most biblically correct position was abandoned in favour of practical considerations in the formation of the BPC.

Before the visitation of the two Deputies we have alluded to above, namely Ashcroft and Houston, there were Deputies who were sent to South Africa in the persons of Revs Melville and Thornton in 1882. My interest is in the report they presented in Scotland after their visitation so Thornton said:

The Wesleyans took a totally different plan from that of the societies, they believed that souls had no colour and so they mixed up black and white in their communion halls. The others sent out colonial ministers who were ordered to keep to the whites, while the missionaries were ordered to minister to the black ("The South African Missions of the Free Church,” 1882:12).

9 For a fuller record of this 1857 decision, see Saayman (1983:135). 
I think we should note that there were others who believed that "souls had no colour." Some chose to divide their ministries on the basis of race. Where do we locate the Scottish missionaries? The case of Lovedale and James Stewart might help us answer this question. I purpose not to repeat the history of James Stewart and Lovedale in this article save to state that what I have already said about him clearly shows that the version of the Scottish missions that became hegemonic in South Africa was racist. In his tenure as principal of Lovedale James Stewart demonstrated how the institutions formed for blacks were used to colonize their minds (Malinge Njeza 2002), or as coercive agents (Duncan 2004) modeling blacks as objects “drinking at the English fountains” (De Kock 1992). James Steward said:

The mind of an African is empty, and he has a great idea of what he calls "getting knowledge." Hence his anxiety about instruction merely, apart from mental discipline and habit... there is the erroneous idea that manual work is service toil, and mental work is supposed to elevate a man to a highest class... His desire, therefore, is to learn whatever the white man learns. This aspiration is very strong, no matter how slight the knowledge attained of any particular subject. Educational equality is probably looked at as a step to further equality. There is such an idea existing among a small and not very satisfactory class.

Hence there is a strong desire, almost amounting to a craze, for Latin and Greek among a few, though the amount of knowledge gained of such subjects is, of course, useless (in De Kock 1992: 128).

Nothing more can tell how James Stewart was racist and rejected the equality of race than the words cited above. That the anticipated union between the DRC was a factor in consideration is also significant. In 1923 when the Synod of the Church of Central Africa, Presbyterian (CCAP) was formed, the DRC and PCSA delegations were present, rejoicing at the DRC Synod of Nkhoma that joined the CCAP (South African Outlook 1924: 266-267). The strong connection between the PCSA and the DRC does not only attest to the potential of union between the two, but also a similarity of ethos. It is notable that the Scottish Missions actually mobilized the DRC to embark on missions:

The Presbytery of Kaffraria, through the missionaries at Lovedale, resolved to approach the D.R.C., with the view to impressing to that body the great importance of doing whatever can be done for the spiritual good of the said natives stating that this presbytery will most heartily co-operate with the Dutch Reformed Church in such work (Williams 1967:201).

Indeed, this affinity between the two churches cannot rule out the possibility of an ideological affinity. Whatever could be done for the spiritual good of the natives made the Scotts to be open to cooperation with the DRC but also beyond the boundaries of this land, also in Malawi. Within these affinities and the "practical considerations" one has to remember that the Ethiopian 
Movement is a commentary to the whole missionary enterprise in South Africa. That Stewart mentioned the Ethiopian Movement in his arguments related to the formation of the BPC puts the history of the formation of this Church within the conflict between blacks and whites.

Ethiopianism was a reaction to racism in the church and society. Saayman argues that such "practical considerations" became a theological principle from 1930 onwards ultimately leading to the adoption of the Apartheid ideology theologically in the history of our country. Most recently, Tshaka (2010) has argued that Apartheid was a "theologized" politics of the white Afrikaners, indeed this pragmatic concession was an apologia for the division of the church on racial grounds. This notion of "practical considerations" in both these Churches does not refute the fact that there was no theological justification for the concession except that it was empathy to the weakness of some brethren. In the end racism and no one, must have benefited from this. If the BPC was a native experiment, it then logically follows that this was a racist experiment. Insights from the mission work among VaTsonga and what later became known as the Evangelical Presbyterian Church of South Africa are a useful digression. Commenting about the work that the Swiss Mission established around 1874, among VaTsonga, the history of the formation of the Evangelical Presbyterian Church and the methods used by the Swiss missionaries, what Bill says is a mouthful:

It meant that the church would grow from mission stations instead of from Christian communities, that the polity of the indigenous church would be an adaptation of the mission pattern instead of growth from the needs and demands of the indigenous congregations; that the workers would be responsible for the mission of their own Church; that the task of proclaiming the faith and extending the church would be regarded as belonging primarily to the mission (in Maluleke 1993:239).

First Maluleke coins the methods used by the Swiss Missionaries as the Mission Colony Approach. This approach created the dichotomies that he so eloquently paints in the sentiments cited above. There is a distinction between mission stations and Christian communities. The polity of the church founded within and among Africans is fashioned after the polity patterns of the Missionary Church and more importantly not even from the growth of the newly formed Church.

The workers do not belong to the congregation, but the Mission and the task of proclaiming faith primarily still belongs to the Mission Station rather than to the newly founded congregation or congregations. Central ecclesiological questions of church growth and polity are distorted in this approach. The defection takes place within the womb of the formation of the new congregations. This was not only the approach of the Swiss Mission but that of the Scottish Missions too. The mission station became the colony 
of the Scots quite in the same way as the bifurcation of the African state a la Mamdani found expression in the Homeland System of the Apartheid regime. I am inclined to argue that the logic of the formation of a "Native Experiment” is not different from that of Bantustans. By the way, Shepherd of Lovedale, a missionary of in the BPC, did not accept a segregated Church but favoured an indigenous one only on the basis of background, languages, approach and culture. He did not only challenge the "self-governing, self-supporting and self-propagating” concept (Oosthuizen 1970:105), but also reminisced that Africans took to Presbyterianism as fish to water (Oosthuizen 1970:103). That the missionaries considered themselves superior to the people they worked with speaks volumes about the defects and dichotomies I have outlined above. Even further, the fact of the PCSA seeing the BPC as a mission in the negotiations of union was meant to demonstrate how this black Church was lower in dignity that an institution that was formed by a Settler community in South Africa. Shepherd goes further:

They sought to bring into being independent self governing, self-supporting and self-propagating churches, not to create multi-racial churches. The wisdom of that policy, which some would now call a policy of apartheid, is being questioned in some quarter, and so union with multiracial churches is being sought (Oosthuizen 1970: 105).

This is how we should view the notion of "practical considerations," a policy whose wisdom some would call Apartheid.

At the beginning of the last century, before 1923 when the BPC was formed, we cannot ignore the characteristic capitalist mode of production that became dominant and the Victorian Expansionism that synchronized with the missionary ethos. Phillipe Dennise says " The churches and missionary societies played a crucial role in the shaping of South African culture as much in the colonial period as during the years of the formation of the Union and the apartheid era" (1997: 85).

Indeed at the beginning of the 20th century, South Africa was experiencing the "Industrial Revolution." There was cheap labour, the migrant labour system, exclusion from political as the Treaty of Vereeniging which ended the Anglo - Boer War indicated after the formation of the Union. There was the opprobrious Land Act of 1933, and the loss of social cohesion with laws following World War I which made the acquisition of skills a sole privilege for whites. What else can explain the formation of a 'Native Church' in the light of these socio-political and ecclesial circumstances? Within an intertwined missionary and colonial culture a defective culture of South Africa emerged. 


\section{The Defects of faith Transplanted on African Soil}

Black Theology of liberation in whose framework the evaluation of the historical text of the formation of the "Native Church" and the reasons propounded for its formation requires us to conclude this reflection by taking cognizance of the defects of faith that came with this experiment discussed above. Blacks found themselves on the underside of modernity with all its pitfalls. They were 'named,' 'signified' and objectified as a people without reason on racial grounds.

\section{Conclusion}

I must state at this juncture that the BPC which was renamed the RPC in 1976 united with the PCSA in 1999 to form the Uniting Presbyterian Church in Southern Africa (UPCSA) after seventy five years of its existence.

The seventy five year history of its existence might yield interesting insights which cannot be covered in this essay due to limited space. First, that history shows that the struggle against the defects of faith transplanted at the very beginnings of the BPC right into its dissolution in 1999, continuing into the UPCSA is a matter of faith. What this implies is that the emphasis of socio-political praxis in Black Theology of liberation is faith confessed in the struggle for life. Second, and much related to this first point is that this history, it must be stated, is not unique to the BPC members, but points to a deeper question we must address in the post 1994 South Africa, namely, the entrapment of black faith in the colonial, Enlightenment defects, yes, the 'missionary station,' or 'Berlin Conference Zone' all of which depict what in Black Theology of liberation is the exclusion of the non-person. The implication here is much deeper as it might imply that the continued entanglement into the defective models and zones of being transplanted through modernity and the Enlightenment, deny the very liberation attained in 1994 through theologies of refusal. Sabelo Ndlovu-Gatsheni, (2013) argues a similar point poignantly in his assessment of the entrapment of Africa within the colonial matrices of power in the twenty first century (2013).

Last, while some have used Bosch's theory of the "paradigm shifts" to explain the encounters between black and white through the Enlightenment paradigm in order to punctuate the contextuality of mission, sometimes even as apologists of missionary defects in Africa, ${ }^{10}$ I cannot deny Bosch's

${ }^{10}$ My reading of Lewis \& Steyn, (2003) who specifically employ Bosch's theory to examine our education landscape in South Africa suggests that we should understand the problem of missionary work in the modernist and enlightenment era as reason more than race and superiority. This point is nuanced, but I also find Bosch making a similar suggestion (1991:344) in his attempt to pointing out the remarkable contribution the Western missionary enterprise contributed of the late twentieth century. 
insights which enable us appropriate mission theology for our time and future. Indeed his theme of "relevant missiology" is profound and taken up very well by Oborji particularly the latter's identification of the emerging paradigms of ecumenical dialogue, Inculturation and liberation.

Most recently, James Harris (2012) has simply argued that indigenous language is indispensable for the future of mission. If the BPC was a defective Enlightenment experiment, Black Theology of liberation cannot overlook that Karl Marx or Du Bois for example were critiques of the Enlightenment paradigm right at its beginnings and in its heydays, furthermore, under whose underside irrupted faith that yearns for liberation, Inculturation and reconciliation in a world that cries for peace and justice in the twenty first century. Written not specifically as a missiological reflection, the implications of the text of the BPC at its formation are not only missiological but manifold. These matters could have been more emphasized, but the 'Native Experiment' whose history is not that much well known.

\section{References}

Bosch, D. J. 1991. Transforming Mission: Paradigm Shifts in Theology of Mission. Maryknoll, New York: Orbis.

Boesak, A. 2009. Running with Horses: Reflections of an Accidental Politician. Cape Town: Joho Publishers.

De Kok 1992. "Drinking at the English Fountains”: Missionary Discourse and the Case of Lovedale. Missionalia 22:116-138.

Denis, P. 1997. From Church History to Religious History. Journal of Theology for Southern Africa, 99: 94-98.

Duncan, G. A. 2003. Lovedale-Coercive Agency: Power and Resistance in Mission Education. Pietermaritzburg: Cluster Publications.

Gqhubule, S. 1977. An Examination of the Theological Education of Africans in the Presbyterian, Methodist, Congregational and Anglican Churches in South Africa from 1860-1960. Unpublished thesis. Grahamstown:, Rhodes University.

Harries, J. 2012. Theory to Practice in Vulnerable Mission: An Academic Appraisal. Eugene:. Wipf and Stock Publishers.

Lewis, A. \& Steyn, J.C. 2003. A Critique of Mission Education in South Africa according to Bosch's Mission Paradigm Theory. South African Journal of Education. 23 (2): 101-106.

Long, C. H. 1986. Significations: Signs, Symbols, and Images in the Interpretation of Religion. Philadelphia: Fortress Press.

Maluleke, T.S. 1993. Mission, Ethnicity and Homeland - the case of the EPCSA. Missionalia 21(3): 236-252

Ndlovu-Gatsheni, S.J. 2013. The Entrapment of Africa within the Global Colonial Matrices of Power: Eurocentrism, Coloniality and Deimperialization in the 
Twenty-first Century. Journal of Developing Societies 29(4): 331-351. DOI:10.1177/0169796X13503195.

Nissen, C. 1989. The study of Missionary Origins of the Reformed Presbyterian Church in Southern Africa. Unpublished manuscript.

Njeza, M. M. 2000. "Subversive Subservience”: A Comparative Study of the Responses of Tiyo Soga and Mpambani Mzimba to the Scottish Missionary Enterprise. Unpublished thesis. Cape Town: University of Cape Town.

Oduyoye, A. M. 2001. Three Cardinal Issues of Mission in Africa. In Mission in the Third Millenium. Edited by Schreiter, R. J. Maryknoll, New York: Orbis. 40-52.

Oborji, F. A. Concepts of Mission: The Evolution of Contemporary Missiology. Maryknoll, New York: Orbis.

Oosthuizen, G.C. 1970. Shepherd of Lovedale. Johannesburg: H. Keartland Publishers.

Saayman, W. A. 1983. The Case of South Africa: Practice, Context and ideology, in Exploring Church Growth. Edited by Shenk, W. R. Grand Rapids, Michigan: William B.Eerdmans. 132-143.

The Christian Express. 1882. "The South African Missions of the Free Church," 11-12.

Tshaka, R.S. 2010. Confessional Theology? A critical analysis of the theology of Karl Barth and its significance for the Belhar Confession. Newcastle: Cambridge Scholars Publishing

Van der Spuy, D. 1971. The Origins of the Bantu Presbyterian Church of South Africa. Unpublished BD dissertation. Grahamstown: Rhodes University.

Xapile S. P 1992. Unity Negotiations Between the Bantu Presbyterian Church and the Presbyterian Church of South Africa. Unpublished Master's dissertation. Cape Town: University of Cape Town..

Xapile, S. P. 2000. The Quest for Unity between the Bantu Presbyterian Church of South Africa and the Presbyterian Church of Southern Africa 1958-1973. Unpublished thesis. Stellenbosch: University of Stellenbosch.

William, D. 1967. When Races Meet: The Life and Times of William Rtichie Thompson, Glasgow Missionary Society: Missionary, Government Agent and Dutch Reformed Minister. Johannesburg: A.B.P. 